\title{
The Expression Analysis of Nanog in the Developing Rat Myocardial Tissues
}

\author{
Zhi-kun Guo Kang Guo $^{\mathrm{b}}$ Huanhuan Luo ${ }^{\mathrm{a}}$ Ling-min Mu $\mathrm{Mu}^{\mathrm{a}}$ Qiong Li ${ }^{\mathrm{a}}$ \\ Yu-qiao Chang $^{\text {a }}$
}

${ }^{a}$ Key Laboratory for Medical Tissue Regeneration of Henan Province, ${ }^{b}$ Tumor Department, Third Affiliated Hospital, Xinxiang Medical University, Xinxiang City, P. R. China

\section{Key Words}

Nanog $•$ Immunohistochemistry $\cdot$ Western blotting $\cdot$ RT-PCR $•$ Myocardial tissue $\cdot$ Rat heart

\begin{abstract}
Objectives: To investigate the expression dynamic of nanog gene in the development of rat myocardial tissues. Methods: SD rats were studied at 5 time points before and after birth. The techniques of immunohistochemistry, immunofluorescence, western blotting and RTPCR were used to investigate the expression of nanog gene in the rat myocardial tissues at different embryonic $(E)$ and postnatal $(P)$ stages, and image analysis system was used for the quantitative analysis. Results: The immunohistochemistry, immunofluorescence and western blotting analyses have shown that expression of nanog protein was highest in the rat myocardial tissues at E18, then it gradually declined at postnatal stages $(P<0.05)$, and became nearly undetectable in most myocardial tissues at P30 with very few remaining nanogpositive cells. RT-PCR result indicated that the expression of nanog gene was strong at E18, but gradually decreased from E18 to P30. Conclusion: The mRNA transcription and protein translation of nanog gene in the rat heart gradually decreased with every consecutive growth stage. This indicates that nanog gene has potential regulatory functions in the differentiation of myocardial cells during rat development.
\end{abstract}

Copyright (C) 2015 S. Karger AG, Basel

\section{Introduction}

Nanog gene, as a youth related gene, is mainly expressed in undifferentiated stem cells. It is a major phenotype marker for pluripotent stem cells and it plays important roles in the self-renewal of stem cells [1-4]. Human nanog mRNA exhibits high expression level 
in the embryonic carcinoma (EC) and embryonic stem cell (ESC), and it has been shown to significantly decline after differentiation of human embryonic stem cell (hESC) $[5,6]$. Recently, several studies on the structure of nanog gene, its expression in ESCs, tumor and genital cells, as well as its involvement in the maintenance of undifferentiated status of multipotential cells have been performed [7-9]. However, the information on expression dynamic of nanog in prenatal, neonatal and adult cardiac tissue is still lacking.

The present investigation for the first time utilized different techniques to study the expression of nanog protein in the cardiac muscle of normal rats at different developmental stages. This study aimed to investigate the behavior of nanog gene in myocardial tissues at mRNA and protein levels, and to provide biological data about the role of nanog gene in the mechanism of differentiation and regeneration of myocardial tissues. The nanog protein in rat myocardial tissues is mainly detected in myocardial cells and its presence gradually decreases in the process of heart development. The mRNA transcription and protein translation of nanog gene is detectable in the rat heart only at embryonic stages but not after birth. The presence of nanog protein translated at the embryonic stages is still detectable after birth. Our results indicate that nanog gene has potential regulatory functions in the differentiation of myocardial cells during the rat heart development.

\section{Materials and Methods}

\section{Animals}

98 SD rats were divided into groups of immunohistochemistry, immunofluorescece, western blotting and RT-PCR. The groups are listed in Table 1 . The fetuses of 18 days were counted as $0.5 \mathrm{~d}$ at the day when vaginal plug could be observed.

The rats were purchased from the Center of Experimental Animals of Henan province and raised with standard particle feed and water. The use and handling of animals in this study was compliant with the rules of the Experimental Animal Committee, Xinxiang Medical University. The rat heart tissues were collected from embryos at mean of embryonic 18 days (E18), from postnatal (P) rat, mean of P5, P10, P20, and P30, respectively. Same number of rats was used for Western blotting and RT-PCR at each stage. To reduce the pain, all of the rats were sacrificed by cervical dislocation and their hearts were rapidly collected. The dissected hearts were fixed in $4 \%$ paraformaldehyde at $4^{\circ} \mathrm{C}$ for $5 \mathrm{~h}$, and then kept in $30 \%$ sugar phosphate buffer at $4^{\circ} \mathrm{C}$ overnight for immunostaining. Adjacent frozen sections were cut in $25 \mu \mathrm{m}$ thickness using a cryostat microtome (Leica CM1850) and stored at $-25^{\circ} \mathrm{C}$ for further use. For Western blotting and RT-PCR, the heart tissues were kept at $-80^{\circ} \mathrm{C}$.

\section{Immunostaining}

Immunochemistry was carried out following ABC staining method. The frozen sections were rinsed with $0.01 \mathrm{~mol} / \mathrm{L}$ PBS for 3 times, $5 \mathrm{~min}$, at room temperature. The activity of endogenous peroxydase was blocked with $3 \% \mathrm{H}_{2} \mathrm{O}_{2}$ for $20 \mathrm{~min}$, then the slides were rinsed 3 times with PBS. Non-specific antigens were blocked with goat serum at room temperature for $20 \mathrm{~min}$. Subsequently, Nanog antibody (diluted in PBS, 1:200; Sigma) was added and incubated in an incubator at $37^{\circ} \mathrm{C}$ for $1 \mathrm{~h}$, then at $4^{\circ} \mathrm{C}$ overnight. On the second day, the slides were rinsed with PBS for 3 times, $5 \mathrm{~min}$ per time, at room temperature. After biotin-labeled secondary antibody $(1: 200)$ was added and incubated at $37^{\circ} \mathrm{C}$ for $30 \mathrm{~min}$, the slides were washed with PBS 3 times, $5 \mathrm{~min}$. Subsequently, ABC complex (ABC kit purchased from Zhongshan Reagent Company) was added dropwise and some of the sections were subjected to hematoxylin counter staining. The samples were subjected to conventional dehydration, clearing, neutral gum mounting and observed under a light microscope.

Other sections were rinsed with $0.01 \mathrm{~mol} / \mathrm{L}$ PBS for $5 \mathrm{~min} \times 3$ times at room temperature. Then the sections were digested with compound digestion solution at $37^{\circ} \mathrm{C}$ for $1 \mathrm{~h}$ and then rinsed with PBS for 5 $\min \times 3$ times. They were blocked with goat serum and then incubated at room temperature for 20 min. Nanog antibody (1:200) was added and the sections were incubated at $37^{\circ} \mathrm{C}$ for $1 \mathrm{~h}$ and then kept in a refrigerator at $4^{\circ} \mathrm{C}$ overnight (in a moist box). The sections were then rinsed with PBS for $5 \min \times 3$ times. Immunofluorescence labeled secondary antibody (from Sigma) was added and the sections were incubated 
Guo et al.: The Expression of Nanog in Rat Myocardial Tissues

Table 1. The groups of experimental animal $(\mathrm{x} \pm s)$. Note, $\mathrm{ABW}$, average body weight; P, postnatal

\begin{tabular}{|c|c|c|c|c|c|c|c|c|c|c|}
\hline & \multicolumn{2}{|r|}{$18 \mathrm{~d}$ fetus } & \multicolumn{2}{|r|}{ P 5-6 d } & \multicolumn{2}{|r|}{ P 9-12 d } & \multicolumn{2}{|r|}{ P 19-21 d } & \multicolumn{2}{|r|}{ P $30 \mathrm{~d}$} \\
\hline & $\mathrm{n}$ & $\mathrm{ABW}(\mathrm{g})$ & $\mathrm{n}$ & $\mathrm{ABW}(\mathrm{g})$ & $\mathrm{n}$ & $\mathrm{ABW}(\mathrm{g})$ & $\mathrm{n}$ & $\mathrm{ABW}(\mathrm{g})$ & $\mathrm{n}$ & $\mathrm{ABW}(\mathrm{g})$ \\
\hline Immunohistochemistry & 20 & 4 & 4 & $12 \pm 6$ & 4 & $30 \pm 5$ & 4 & $56 \pm 8$ & 4 & $160 \pm 7$ \\
\hline immunofluorescence & 20 & 4 & 4 & $11 \pm 4$ & 4 & $29 \pm 5$ & 4 & $57 \pm 7$ & 4 & $161 \pm 5$ \\
\hline western blotting & 30 & 6 & 6 & $13 \pm 5$ & 6 & $31 \pm 5$ & 6 & $58 \pm 7$ & 6 & $162 \pm 38$ \\
\hline RT-PCR & 30 & 7 & & & 7 & $11 \pm 11$ & 7 & $58 \pm 7$ & 7 & $188 \pm 6$ \\
\hline
\end{tabular}

at $37^{\circ} \mathrm{C}$ for $30 \mathrm{~min}$, then they were rinsed with PBS for $5 \mathrm{~min} \times 3$ times. The sections were mounted with antifade solution and then observed and photographed under fluorescencent microscope.

Some frozen sections were blocked by goat serum, and incubated for $20 \mathrm{~min}$ at room temperature. Nanog antibody (1:200; Sigma) and c-kit antibody (1:300, Sigma) were added, incubated in a moist box at room temperature overnight. Then immunofluorescence secondary antibody labeled by CY3 was added and slides were incubated at $37^{\circ} \mathrm{C}$ for 2 hours. The sections were mounted with fluorescence mounting solution, and imaged using a confocal microscope.

\section{Western blotting}

The samples stored $-78^{\circ} \mathrm{C}$ were homogenized in a glass homogenizer with lysis buffer $(1 \mathrm{ml} / 100 \mathrm{mg}) \mathrm{on}$ ice. After the cell debris and residues were removed by $12000 \mathrm{rpm}$ centrifugation at room temperature, the supernatant was transferred to a fresh tube and again centrifuged at $10000 \mathrm{rpm}$ at $4^{\circ} \mathrm{C}$ for $10 \mathrm{~min}$. The proteins concentration in the final supernatant was determined using a NanoDrop ND 2000 spectrophotometer. According to the concentration, certain volume containing $40 \mu \mathrm{g}$ proteins of each sample was mixed with $2 \times$ loading buffer.

For SDS-PAGE, the mixture (sample and loading buffer) were boiled for protein denaturation at $100^{\circ} \mathrm{C}$ for $5 \mathrm{~min}$. Then the samples were added to the wells of the $10 \%$ gel. $10 \mu \mathrm{l}$ of pre-stained protein marker was added as a control. When the samples in the 5\% condensing gel running with a voltage of $70 \mathrm{~V}$ reached the separation gel, the voltage was adjusted to $100 \mathrm{~V}$ until the frontier of the coloring agent, bromchlorphenol blue, reached the gel bottom. Then the proteins were transferred from gel to a PVDF membrane with a membrane transferring apparatus under $110 \mathrm{~mA}$ for $2 \mathrm{~h}$. PVDF membrane containing proteins after transfer was rinsed with $1 \times$ TBS-T for 5 min $\times 3$ times, with a shaker.

$5 \%$ non-fat milk liquid was used to block the unspecific proteins. The blocked membrane was then placed in a hybridization bag, and nanog and $\beta$-actin primary antibodies were added at 1:500 and 1:200 dilutions, respectively. The bag was then sealed and incubated at $4^{\circ} \mathrm{C}$ overnight. On the second day, the membrane was rinsed 3 times x 10min. Subsequently, the membrane was incubated with diluted (1:10000) HRP-conjugated secondary antibody (goat anti-rabbit-HRP) at room temperature for $1 \mathrm{~h}$, and then rinsed for 3 times x 10min. Proper amount of DAB coloration solution was added on the blotting membrane until significant brown coloration bands could be found. Lastly, the hybridization membrane was rinsed with water to stop the reaction.

\section{Isolation of total RNA and RT-PCR}

The total RNA was isolated from the frozen heart tissues with an AxyPrep general RNA minipreparation kit (Invitrogen). Single strand cDNA was reverse transcribed with Oligo(dT) and reverse transcriptase (RT) M-MLV retroviridase (Promega). For following PCR, the upstream and downstream primers of nanog gene were 5'-gtctgctactgagatgctct-3' and 5'-atctgctggaggctgaggta-3', respectively. The upstream and downstream primers of $\beta$-actin gene, which served as an internal control, were $5^{\prime}$-cacccgcgagtacaaccttc-3' and 5'-cccatacccaccatcacacc-3', respectively. The expected amplified fragments length for nanog gene and $\beta$-actin were $250 \mathrm{bp}$ and $500 \mathrm{bp}$, respectively. The PCR reaction was carried out as follows: pre-denaturation for $5 \mathrm{~min}$ at $94^{\circ} \mathrm{C}$, then 33 cycles (denaturation for $30 \mathrm{~s}$ at $95^{\circ} \mathrm{C}$, annealing for $60 \mathrm{~s}$ at $72^{\circ} \mathrm{C}$, and extension for $60 \mathrm{~s}$ at $72^{\circ} \mathrm{C}$ ), and final extension for $10 \mathrm{~min}$ at $72^{\circ} \mathrm{C}$. The PCR reaction products were detected by agarose gel electrophoresis and imaged using Chemilmager TM 5500 gel formatter.

\section{KARGER}


Fig. 1. Nanog protein expression in the rat cardiac tissue at different developmental stages analyzed by immuohistochemistry. The buffy color from section immunostaining shows nanog protein is strongly expressed of at E18 (A), then gradually decreased at P5 (B), P10 (C) and P20 (D). The positive signals in C and D outline the cross-section of blood capillaries. The illustration in D is a magnification of small vessel which was circled by endothelial cells $(\uparrow)$. Statistical analysis was shown as a bar graph (E). The error bars represent means $+/-$ s.e.m. $(n=5) . P<0.01$.
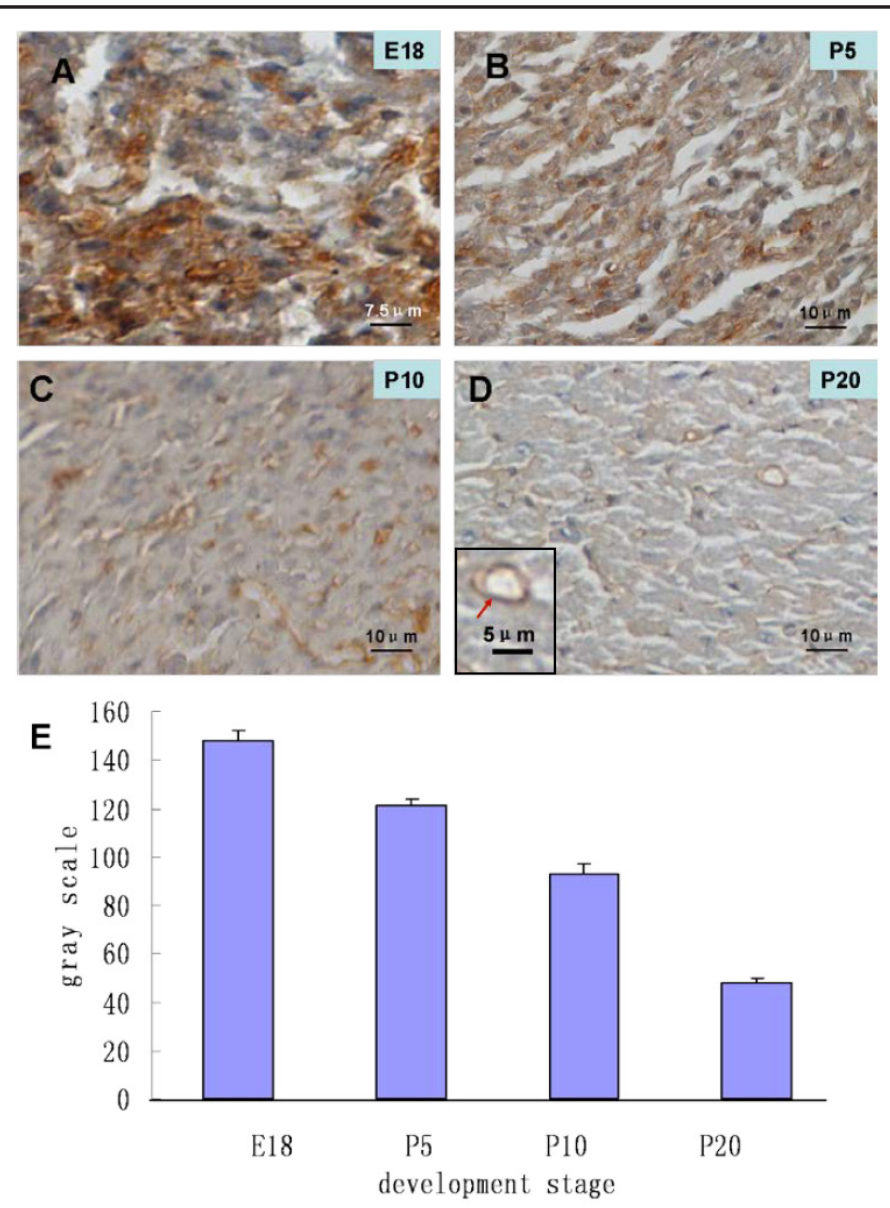

Image processing and statistical analysis

The sections with immunostaining were subsequently subjected to quantitative analysis with the high-resolution Motic Images Advanced software (Motic Company). Ten fields of view were selected from each stage group under the $20 \times$ magnification. Mean gray value (i.e. gray scale in histograms) was used to represent the intensity of the signal.

The gray values for the target bands in the Western blotting and RT-RNA results were also determined. The values of target bands were normalized against control $\beta$-actin. The final ratio between target band and $\beta$-actin were analyzed by $t$-test. The data are shown with the standard error of the mean (s.e.m; $n=8$ ). The difference with $\mathrm{P}<0.05$ using $t$-test was considered as statistically significant.

\section{Results}

We have investigated RNA and protein expression profiles of nanog gene during rat heart development, (Figs. 1, 2, 3). The results show that the nanog mRNA transcription and protein content are temporally different. mRNA and protein of nanog gene are only generated in the rat heart at embryonic stages although nanog protein can be detected at postnatal stages.

The nanog protein expression during rat heart development

Nanog protein showed strong positive expression in the cardiac muscle cells at the embryonic stage. The positive signal in cardiac muscle cells gradually weakened or even disappeared after birth (Fig. 1). Nanog protein showed lamellar uneven expression pattern in the myocardial tissues at the fetus stage. For example, at E18, nanog protein was mainly detected in the cytoplasm of cardiac muscle cells but not in the cell membrane and nuclei (Fig. 1A). Endothelial cells of the endocardium also showed similarly strong positive expression, 
Fig. 2. Nanog protein immunofluorescence expression of rat cardiac tissue in different developmental stages. The red color shows nanog protein. It is highly expressed at E18(A), and then gradually declines at P6 (B), P10 (C) and P19 (D). Notably, the lowest expression was observed at P19.

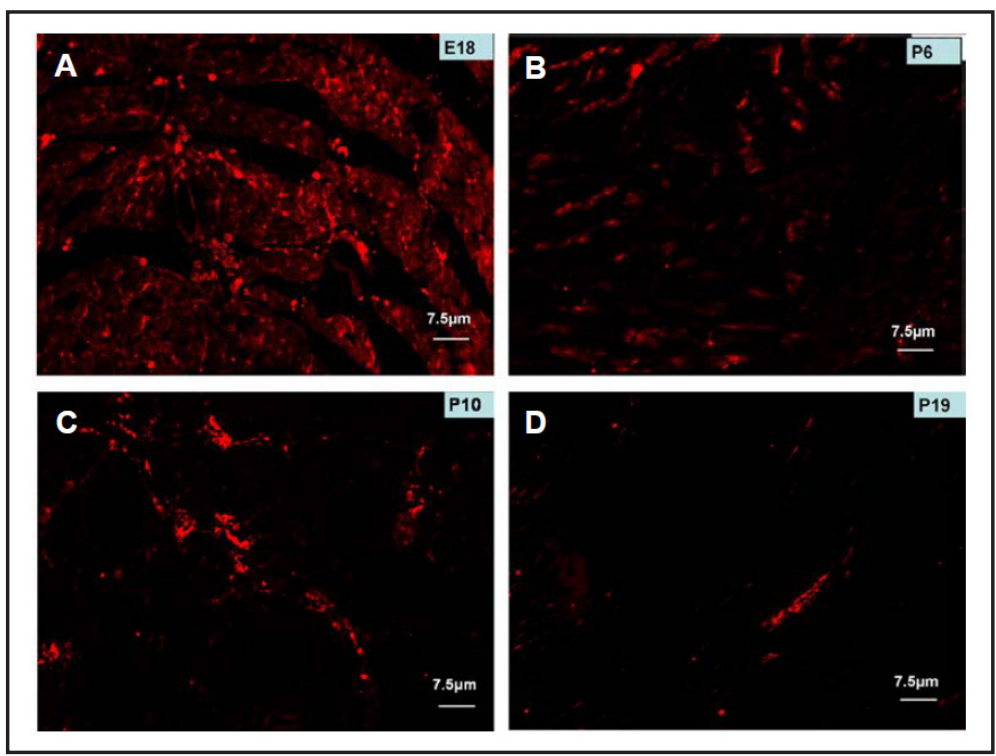

Fig. 3. Nanog protein expression in a few cardiomyocytes $(\uparrow)$ of rat ventricular tissue at postnatal 30 day. Immunohistochemical staining $(\mathrm{A})$, counterstaining with hematoxylin (B and C) and immunofluoresence staining $(\mathrm{C})$.

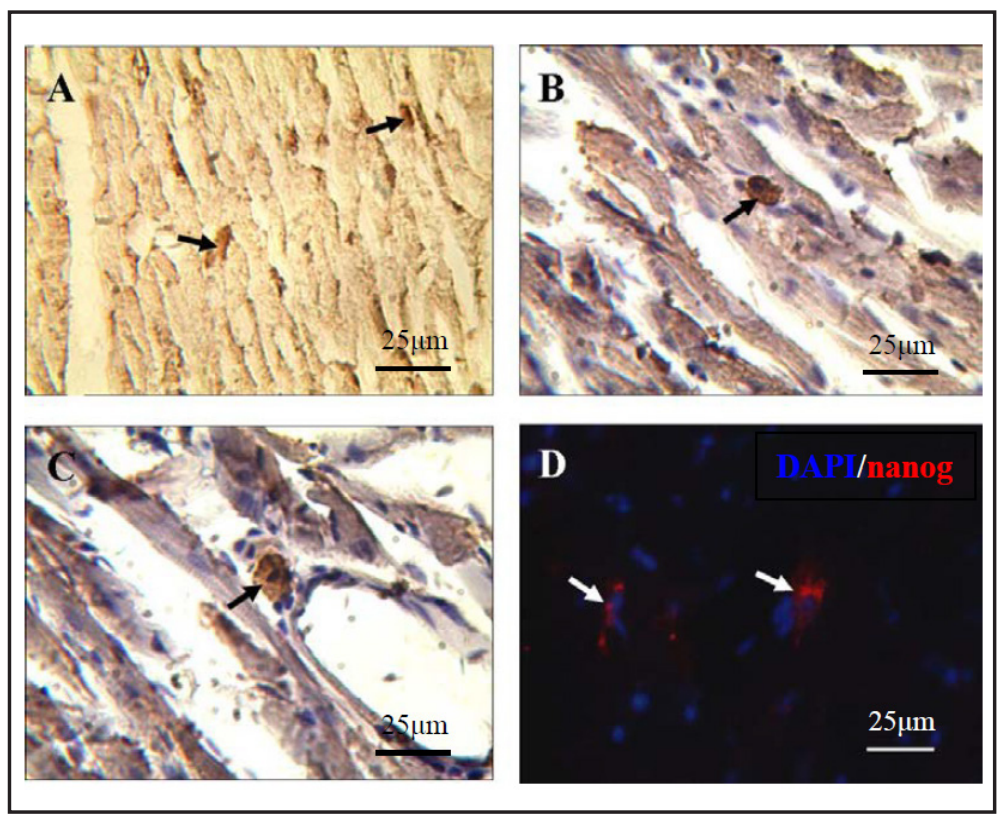

Fig. 4. Co-expression of c-kit and nanog in rat vebtricular tissue at postnatal day. $\mathrm{C}$ was merged $\mathrm{A}$ and $\mathrm{B}$.
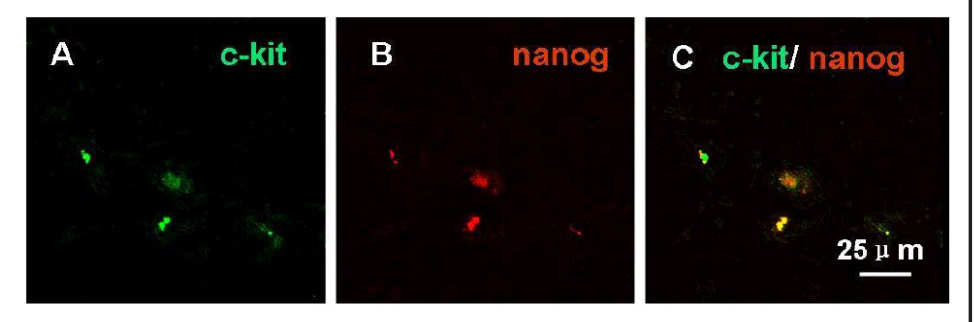

the capillary endothelial in the cardiac muscle seldom showed positive expression. At P5, nanog protein expression was clear in cytoplasm of cardiac muscle cells, but showed extremely weak positive or negative reactions in the myocardial tissues (Fig. 1B). At P10, most of the cardiac muscle cells showed very low protein expression (Fig. 1C). The expression of nanog in capillary endothelial cells, endothelial cells of relatively big blood vessels and endocardium was detectable. It showed dark brown coloration rings on the transverse section of blood capillaries (Fig. 1C, D) and linear expression on the longitudinal section. At 
Fig. 5. Nanog protein expression in the rat cardiac tissue at different developing stages with western blotting analysis(A). Nanog protein is most strongly expressed at means of E18-20, then gradually decreased after birth, and negative at mean of P30. Statistical analysis was shown as column diagram (B).The error bars represent means +/-s.e.m. $(n=5) . P<0.01$.
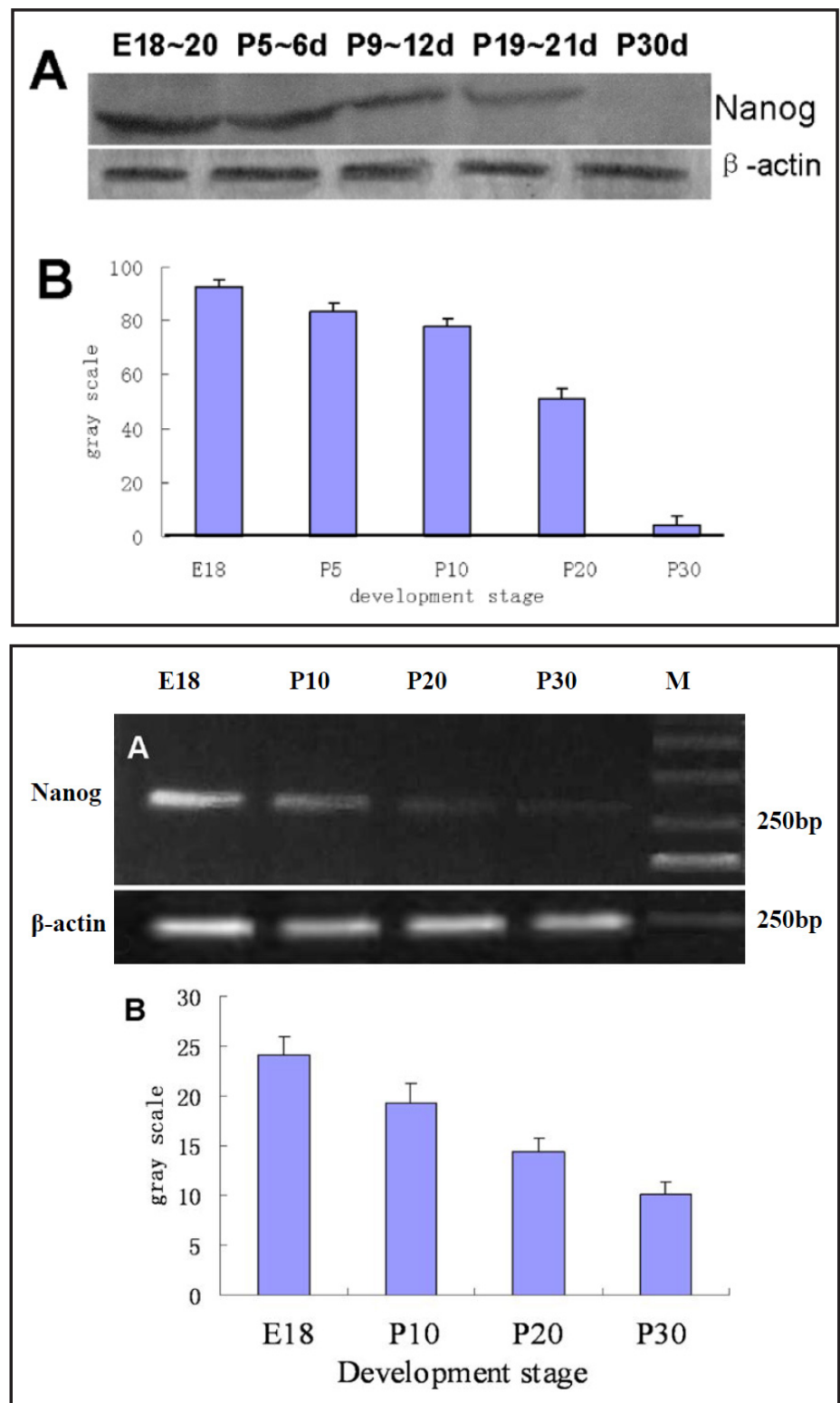

P20, most of the endothelial cells in the endocardium still showed positive expression, and few of them were weakly positive, but almost non-existent in the cardiac muscle (Fig. 1D). The quantitative analysis of the overall immunostaining have shown consistent decline of nanog protein expression after birth (Fig. 1E).

Similar trends were observed with fluorescent immunostaining. The signal was mainly distributed in the cytoplasm of cardiac muscle cells. Nanog protein showed strong positive expression in the cardiac muscles of E18 rat fetuses (Fig. 2A-E18). After birth, the expression of nanog protein in the cardiac muscles became progressively weaker reaching the lowest level at P19 although some cells showed strong positive expression (Fig. 2D-P19). The expression in the cardiac muscle cells was regional or dispersed in the rats of 30 days old. These results were in good accordance with the HRP-based immunohistochemical results.

Nanog protein was scarcely expressed (HRP) in ventricular tissue of rat in P30 with only very few round or elliptical cellsshowing high expression. Nanog-positive cells were located between cardiac myocytes (Fig. 3A,B) or around small vessels between fibrocytes (Fig. 3B,C). Existence of those few nanog cells of cardiac tissue in postnatal 30 days was further confirmed by immunofluorescence expression (Fig. 3D). A double immunostaining for nanog and c-kit have shown that both nanog and c-kit were co-expressed in the cytoplasm (Fig. 4). 
To further analyze the developmental expression profile of nanog protein in the rat heart, we carried out western blotting analysis. The myocardial tissues at E18 showed strong expression and that gradually weakened after birth, and virtually disappeared at P30 (Fig. $2 \mathrm{~A}$ ). The quantitative results of the images by computers were shown in in a bar graph (Fig. 2B).

\section{mRNA expression changes of nanog gene}

The transcription of nanog gene was very active in cardiac tissue at the embryonic stage E18 and practically disappeared at P5. $(P<0.05$, Fig. $3 A, B)$. These results indicate that nanog mRNA is only transcribed in the rat heart at embryonic stages, not after birth.

\section{Discussion}

Nanog is a homeodomain protein expressed in multipotential cells and developing embryonic cells of mammals, which serves as a key marker of embryonic stem cells (ESCs). Re-expression of nanog gene transforms somatic cells into ESCs. The depletion of nanog protein can lead to early embryonic death, cause aberrant migration of primordial germ cells (PGCs) and inhibit the expression of Cxcr4b in PGCs $[10,11]$. Therefore, nanog can be considered as one of crucial component transcription factors responsible for multipotency and transition of somatic cells to multipotency [12].

The immunohistochemical and immunoflouresence results in this study showed that the concentration of nanog protein in cardiac muscle cells at embryonic stage was relatively high and distributed diffusely in the cytoplasm, and that its concentration gradually decreased towards the completion of the developmental program (Fig. 1,2). Western blotting showed that nanog protein had no expression at P30 (Fig. 4). The result from RT-PCR showed that expression of nanog gene was high at embryonic stage, and gradually became lower at postnatal stages (Fig. 5).

All results showed that nanog expression gradually decreased with the heart development. This indicates that nanog protein has important regulatory functions on the differentiation and development of cardiac muscle cells. It is of interest to note that the most of cardiac myocytes had ceased to express nanog at P30, but some very few small cells located among cardiac myocytes and around small vessels were still highly positive. The morphology of remaining nanog-positive (Fig. 3A,B) was very similar to morphology of cardiac stem cells described by Urbanek [13]. Therefore, we presume that these small nanog expressing cells should play an important role during cardiac regeneration. Nanogpositive cell were located in the niches formed by fibrocytes (Fig. 3C). These niches create microenvironment that protects, maintains properties and prevents damaging stimulation of nanog-positive cells $[13,14]$.

It is generally considered that cardiac muscle cells are highly differentiated and lack the capability for division and proliferation at the adult stage. Our earlier studies have shown that cardiac muscle cells can divide and proliferate during the embryonic stage and for a short period after birth, but the cardiomyocytes in adults undergo mitotic division very rarely [15]. The results of this study showed that nanog expression occurred within the time frame of active division of cardiac muscle cells, which is suggestive of its involvement in these processes. So far, the targets for nanog protein have not been elucidated. Nanog protein has no effect on terminal differentiation and acts as an inhibitor of trans-differentiation that depends on de novo activation of gene transcription [16]; therefore, highly differentiated cardiac muscle cells re-enter the division cycle via restarting nanog gene, when injured [17].

The stem cells that are c-kit-positive are most frequently found in adult heart (one for every $10^{4}$ myocyte on average). They have the properties of cardiac stem cells and are selfrenewing. When injected into an ischemic heart, theses cells reconstruct well-differentiated myocardium comprised of myocytes with the characteristics of young cells and supported by newly formed blood vessels $[18,19]$. Nanog is also a marker of totipotency and multipotency 
of stem cells [6]. Co-expression of nanog and c-kit observed in this study further confirmed that small nanog-positive cells were, in fact, cardiac stem cells in adult heart.

The comparison of current data with our previous study on nanog in mouse cardiac muscles showed that the period of termination of nanog protein expression in the rat cardiac muscles was longer (18 days), since nanog protein in the mouse cardiac muscles almost did not express at P12 [20]. This suggest species-specific differences in nanog expression dynamic. Furthermore, present study demonstrated that shifts in mRNA and protein expression were highly concordant at different developmental stages. It is unknown why nanog activity does not persist beyond early postnatal stages but, according to the present study, highly nanogpositive small cells may be maintained in small numbers during a lifetime.

Within a period from embryonic to postnatal stages, blood capillaries rapidly develop to support increase of myocardial contractile force and thickening of cardiac wall. Endothelial cells actively proliferate and they need nanog protein during the process of division and proliferation. Our present results showed that the expression of nanog protein in the endothelial cells at embryonic and postnatal stage was significantly increased in comparison to cardiac cells and fibrocytes, indicating that this regulatory factor played important roles in the division and proliferation of endothelial cells. This results was in accordance with our previous results on mice [20].

\section{Acknowledgements}

We thank the colleagues of our laboratory for discussion. This work was supported by a grant from the National Natural Sceince Foundation of China (30740069).

\section{Disclosure Statement}

The authors have no competing interests to declare.

\section{References}

1 Singh AM, Hamazaki T, Hankowski KE, Terada N: A heterogeneous expression pattern for Nanog in embryonic stem cells. Stem Cells 2007 25:2534-2542.

-2 Vallier L, Mendjan S, Brown S, Chng Z, Teo A, Smithers LE, Trotter MW, Cho CH, Martinez A, Rugg-Gunn P, Brons G, Pedersen RA: Activin/Nodal signalling maintains pluripotency by controlling Nanog expression. Development 2009;136:1339-1349.

-3 Hart AH, Hartley L, Ibrahim M, Robb L: Identification cloning and expression analysis of the pluripotency promoting Nanog genes in mouse and human. Dev Dyn 2004;230:187-198.

4 Pan G, Li J, Zhou Y, Zheng H, Pei D: A negative feedback loop of transcription factors that controls stem cell pluripotency and self-renewal. FASEB J 2006;20:1730-1732.

-5 Chambers I, Colby D, Robertson M, Nichols J, Lee S, Tweedie S, Smith A: Functional expression cloning of Nanog, a pluripotency sustaining factor in embryonic stem cells. Cell 2003;113:643-655.

6 Mitsui K,Tokuzawa Y, Itoh H, Seqawa K, Murakami M, Takahashi K, Maruyama M, Maeda M, Yamanaka S: The homeoprotein Nanog is required for maintenance of pluripotency in mouse epiblast and ES cells. Cell 2003;113:631-642.

7 Plaia TW, Josephson R, Liu Y, Zeng X, Ording C, Toumadie A, Brimble SN, Sherrer ES, Uhi EW, Freed WJ, Schulz TC, Maitra A, Rao MS, Auerbach JM: Characterization of a New NIH-Registered Variant Human Embryonic Stem Cell Line, BG01V: A Tool for Human Embryonic Stem Cell Research. Stem Cells 2006;24:531-546.

8 Pereira L, Yi F, Merrill BJ: Repression of Nanog gene transcription by Tcf3 limits embryonic stem cell selfre-newal. Mol Cell Biol 2006;26:7479-7491. 


\begin{tabular}{|c|c|c|}
\hline \multirow{2}{*}{$\begin{array}{l}\text { Cellular Physiology } \\
\text { and Biochemistry }\end{array}$} & \\
\hline & $\begin{array}{l}\text { DOI: } 10.1159 / 000369744 \\
\text { Publishec onIIne: January } 30,2015\end{array}$ & $\begin{array}{l}\text { O } 2015 \text { S. Karger AG, Basel } \\
\text { www.karger.com/cpb }\end{array}$ \\
\hline
\end{tabular}

-9 Hatano SY,Tada M, Kimura H, Yamaquchi S, Kono T, Nakano T, Suemori H, Nakatsuji N, Tada T: Pluripotential competence of cells associated with Nanog activity. Mech Dev 2005;122:67-79.

10 Sánchez-Sánchez AV, Camp E, Leal-Tassias A, Atkinson SP, Armstrong L, Díaz-Llopis M, Mullor JL:Nanog regulates primordial germ cell migration through Cxcr4b. Stem Cells 2010;28:1457-1464.

-11 Yamaguchi S, Kurimoto K, Yabuta Y, Sasaki H, Nakatsuji N, Saitou M, Tada T: Conditional knockdown of Nanog induces apoptotic cell death in mouse migrating primordial germ cells. Development 2009;136:4011-4020.

12 Zhou YY, Zeng FY: Two vital transcriptional factors Oct-4 and Nanog to keep the pluripotency and selfrenewal of stem cells and related regulation network. Hereditas 2008;30:529-536.

13 Urbanek K, Cesselli D, Rota M, Nascimbene A, De Angelis A, Hosoda T, Bearzi C, Boni A, Bolli R, Kajstura J, Anversa P, Leri A: Stem cell niches in the adult mouse heart. Proc Natl Acad Sci USA 2006;103:9226-9231.

14 Fuches E, Tumbar T, Guasch G: Socializing with the neighbors: stem cells and their niche. Cell 2004;116:769-778.

15 Guo ZK, Lin JT, Chang LS, Xu ZP, Cai XH: Features of cardiomyocyte division during rat heart development. Pak J Zool 2011;43:321-330.

-16 Kochupurakkal BS, Sarig R, Fuchs O, Piestun D, Rechavi G, Givol D: Nanog inhibits the switch of myogenic cells towards the osteogenic lineage. Biochem Biophys Res Commun, 2008;365:846-850.

17 Costa AD: Divide to survive: myocardial regeneration and functional recovery after cell cycle activation in injured hearts. Cardiovasc Res 2008;78:1-2.

18 Baker M, Limana F, Chimenti S, Kasahara H, Rota M, Musso E, Urbanek K, Leri A, Kajstura J, Nadal-Ginard B, Anversa P: Cardiac stem cells are multipotent and support myocardial regeneration. Cell 2003;114:763776.

19 Dawn B, Stein AB, Urbanek K, Rota M, Whang B, Rastaldo R, Torella D, Tang XL, Rezazadeh A, Kajstura J, Leri A, Hunt G, Varma J, Prabhu SD, Anversa P, Bolli R: Cardiac stenl cells delivered intravascu1ar1y traverse the vessel barier, regenerate infracted myocardium, and improve cardiac function. Pro Natl Acad Sci USA 2005;102:3766-3771,

20 Wu JF, Han JZ, Guo ZK: Expression of nanog protein in the cardiac tissue of developing mouse. Chin J Anat 2008;31:496-497. 